\title{
Performance evaluation of polycrystalline photovoltaic modules in a Guinea Savanna and Mangrove swamp
}

\author{
Nsed Ayip Akonjom ${ }^{1}$, John Iyang Umuji ${ }^{2}$ and Ukoette Jeremiah Ekah 1,* \\ ${ }^{1}$ Department of Physics, Cross River University of Technology, Calabar, Nigeria. \\ 2 Department of Electrical and Electronics Engineering, Cross River University of Technology, Calabar, Nigeria.
}

World Journal of Advanced Engineering Technology and Sciences, 2021, 04(01), 011-021

Publication history: Received on 20 October 2021; revised on 24 November 2021; accepted on 26 November 2021

Article DOI: https://doi.org/10.30574/wjaets.2021.4.1.0081

\begin{abstract}
This central idea of this research is to investigate how voltage, current, power output and efficiency of polycrystalline photovoltaic (PV) modules installed in a Guinea Savanna and Mangrove Swamp is affected by temperature, relative humidity and irradiance. The study locations are Calabar (mangrove swamp) and Ogoja (guinea savanna), in Cross River State, Nigeria. Two polycrystalline PV modules of exact specification mounted on a platform one-metre-high above the ground were used. A digital solar power meter (SM206) and a digital solar flux meter (MS 6616) was used to monitor and measure solar power and solar flux reaching the PV modules. A digital hygrometer and thermometer (KT-908) were used to monitor and measure the relative humidity and ambient temperature level at the height of installation and a digital multimeter $\left({\left.\mathrm{M} 880 \mathrm{C}^{+}\right)}\right)$accompanied with a temperature sensor was used to monitor voltage, current and panel temperature values from the modules. Analysis of the collected data reveals that the efficiency of the modules were not constant throughout the day. However, a higher voltage production and efficiency level was obtained for the PV module installed in Ogoja than that installed in Calabar under their respective levels of relative humidity, temperature and irradiance.
\end{abstract}

Keywords: Current; Voltage; Efficiency; Power Output; Photovoltaic

\section{Introduction}

The supply of grid electricity in Nigeria is epileptic [1] and this is not unconnected to the dwindling Nigerian economy. The alternative energy source, the generator, makes use of fossil fuel which is costly and whose by-product is harzadous to the environment. To sustain our energy needs, coupled with the surge for a renewable clean and reliable source of energy, solar energy research and utilization has become very important [2-9].

However, solar energy accessibility is influenced by meteorological conditions which regularly vary with time, season and location. Solar radiation striking a target or passing through a transmitting medium is mostly reflected and assimilated, while the rest is transmitted [10]. It is reduced and weakened as it navigates the layers of the atmosphere, keeping a large segment of it from arriving at the surface of the earth. Inside the Earth's atmosphere, scattering is the dominant process that results in attenuation.

Since the photovoltaic system is mainly useful during the day, then the problem is to identify and create a photovoltaic system that is capable of converting and storing enough electrical energy during the day for use at night and this has been investigated by many researchers [11-21].

\footnotetext{
${ }^{*}$ Corresponding author: Ukoette Jeremiah Ekah

Department of Physics, Cross River University of Technology, Calabar, Nigeria.
} 
This work is aimed at determining how the efficiency of a polycrystalline photovoltaic modules in two specific locations in Cross River State is affected by different climatic and geographical parameters.

\subsection{Locations of Study}

In this study, two locations, Calabar and Ogoja, have been chosen for the investigation, both located in Cross River State, Nigeria.

\subsection{Calabar}

Calabar, the capital of Cross River State, located in the southern part of Nigeria, experiences a rare type of climate known as the tropical monsoon climate. Calabar is on Latitude $4^{\circ} 57^{\prime} 06^{\prime \prime} \mathrm{N}$ and longitude $8^{\circ} 19^{\prime} 19^{\prime \prime} \mathrm{E}$ at an elevation of $32 \mathrm{~m}$ above sea level. It experiences precipitations almost throughout the whole year except in the core months of the dry season which occurs in two short periods of January to March and October to December during a calendar year [22]. But the location selected for this study is on Latitude $4.9^{\circ} \mathrm{N}$ and Longitude $8.3^{\circ} \mathrm{E}$, about 400 metres from Ekpo Abasi roundabout.

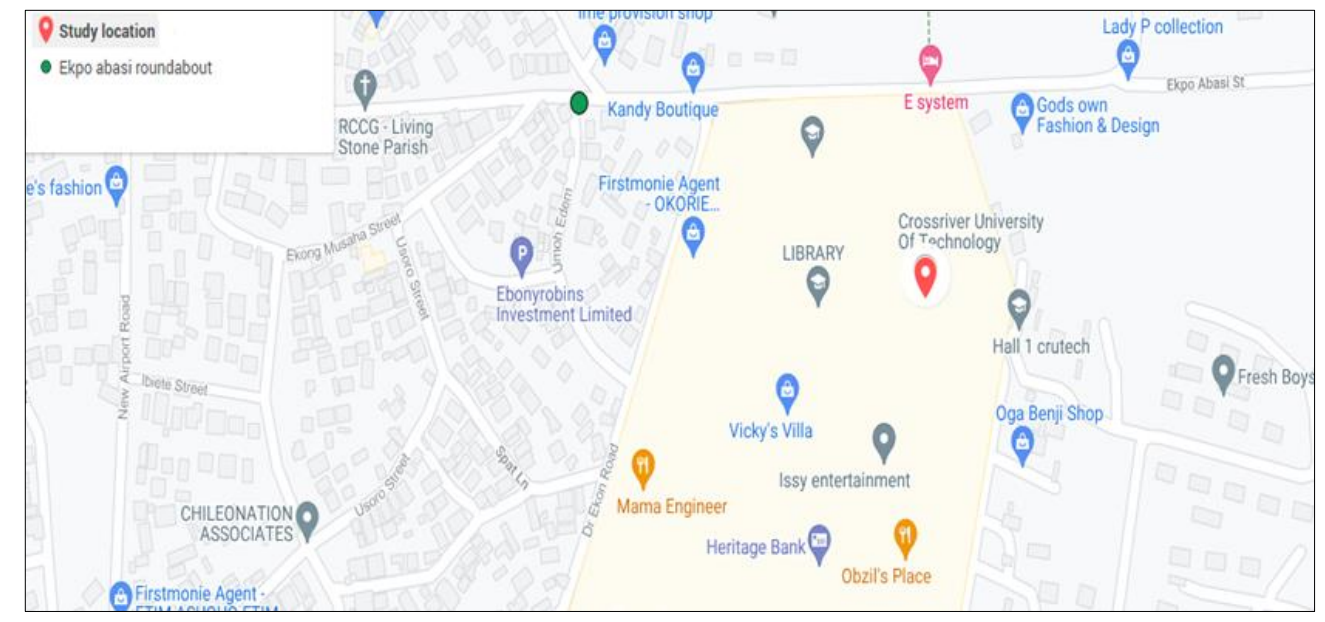

Figure 1 Map of study location in Calabar

\subsection{Ogoja}

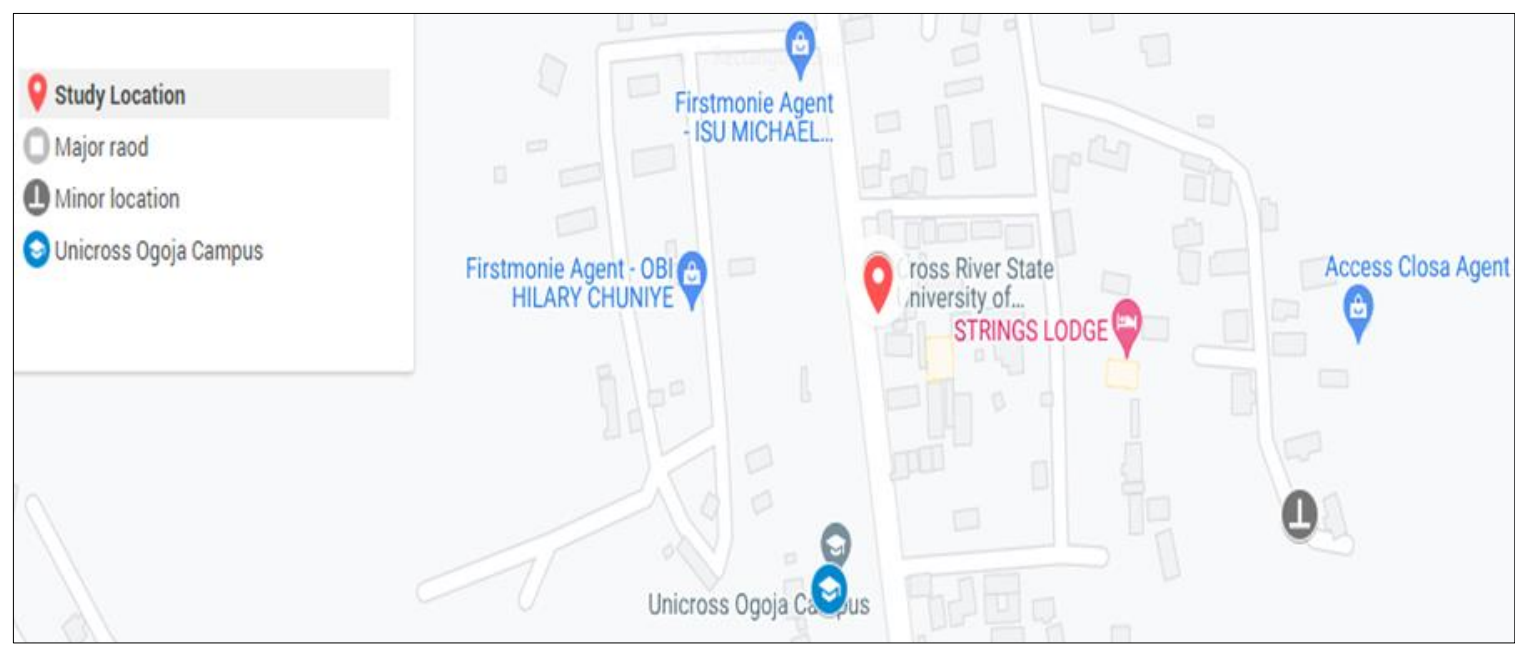

Figure 2 Map of study location in Ogoja

The warmest month, on average, is March with an average temperature of $84.2^{\circ} \mathrm{F}\left(29^{\circ} \mathrm{C}\right)$. The coolest month on average is July, with an average temperature of $77.9^{\circ} \mathrm{F}\left(25.5^{\circ} \mathrm{C}\right)$. Its mean relative humidity is $76 \%$ and the annual wind speed is $3.68 \mathrm{~m} / \mathrm{s}$ [23]. But the location selected for this study is the Cross River University of Technology (CRUTECH) campus, at Ogoja, which is along Mbube road with bearing of Latitude $6.6^{\circ} \mathrm{N}$ and longitude $8.7^{0} \mathrm{E}$. 


\section{Methodology}

Materials used for this research are a digital solar power meter (SM206) and a digital solar flux meter (MS 6616) to monitor and measure solar power and solar flux reaching the PV modules. A digital hygrometer and thermometer (KT908) was used to monitor and measure the relative humidity and ambient temperature level at the height of installation. A digital multimeter $\left({\left.\mathrm{M} 880 \mathrm{C}^{+}\right)}\right.$accompanied with a temperature sensor, to monitor voltage, current and panel temperature values from the modules.

Two polycrystalline PV modules of exact specification mounted on a platform one-metre-high above the ground were used. The manufacturer's (Yingli Solar YS130) technical specifications were given at standard test condition of solar radiation $\left(1000 \mathrm{~W} / \mathrm{m}^{2}\right)$, temperature $\left(25^{\circ} \mathrm{C}\right)$ and air mass $(1.5)$. They are:

Power output at Peak Power - 130W

Voltage at Peak Power $-17.5 \mathrm{~V}$

Current at Peak Power - 7.42A

Open Circuit Voltage $-22.05 \mathrm{~V}$

Short Circuit Current - 8.31A

Module Efficiency - 18.5\%

Surface Area of Module $-0.98 \mathrm{~m}^{2}$

Connecting cables ran from the output terminals of the solar panels to a switch which led to the charge controller. The charge controller output was linked to the battery to assure smooth charging of the battery, and from the battery the load was powered through an inverter. In both locations of study, measurements were taken at an interval of 30 minutes from 6.00 am to $6.00 \mathrm{pm}$ for a period of 31 days in the month of July.

From the readings obtained, the power from the solar panel was determined using (1), the maximum power that the solar panel can give out was ascertained using (2), while the normalized power output efficiency was calculated using (3) as shown by [24]. It has been shown by [12] that the efficiency of a photovoltaic module can be determined using (4). [24] also show that the short circuit current and the open circuit voltage are been influenced by parameters like solar power and temperature as indicated in (5) and (6).

\subsection{Measured Power}

$$
\mathrm{P}_{\text {mea }}=\mathrm{V}_{\text {mea }} \times \mathrm{I}_{\text {mea }}
$$

\subsection{Maximum Power}

$$
\mathrm{P}_{\max }=\mathrm{V}_{\max } \times \mathrm{I}_{\max }
$$

\subsection{Efficiency (Normalized power output)}

$$
\eta_{\mathrm{p}}=\frac{\mathrm{P}_{\mathrm{mea}}}{\mathrm{P}_{\max }} \times 100
$$

\subsection{Module efficiency}

$$
\eta_{\text {mod }}=\frac{\text { Power of solar panel } \times 100 \%}{\text { Area of solar panel } \times 1000 \mathrm{~W} / \mathrm{m}^{2}}
$$

\subsection{Short circuit current}

$$
\mathrm{I}_{\mathrm{sc}}=\mathrm{bH}
$$

\subsection{Open circuit voltage}

$$
\mathrm{V}_{\mathrm{oc}}=\frac{K T}{Q} \ln \frac{I s c}{I o}
$$


Where $P_{\text {mea, }} V_{\text {mea }}$ and $I_{\text {mea }}$ are the measured power, voltage and current respectively. $I_{o}$ is the current at saturation point, $\mathrm{Q}$ is the charge of an electron, $\mathrm{K}$ is the Boltzmann constant, $\mathrm{T}$ is the absolute temperature in kelvin, $\mathrm{H}$ is the intensity of light incident on the solar cell and $\mathrm{b}$ is a constant that strongly depends on the semiconductor junction properties.

The experimental layout of how the photovoltaic module was installed in both locations is presented in Figure 6.

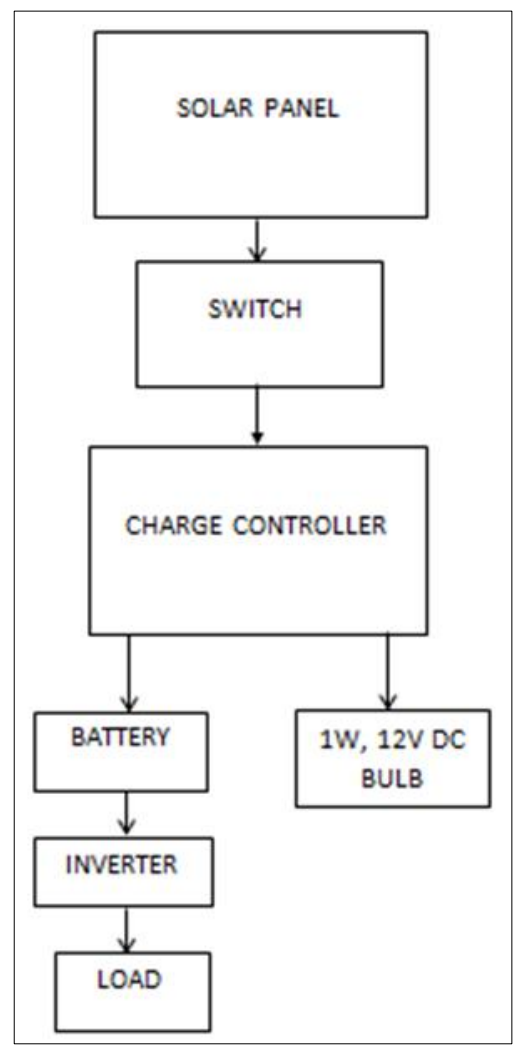

Figure 3 Experimental layout

\section{Results and discussion}

Figure 4 shows the effect of relative humidity on the voltage produced by the photovoltaic modules at both locations.

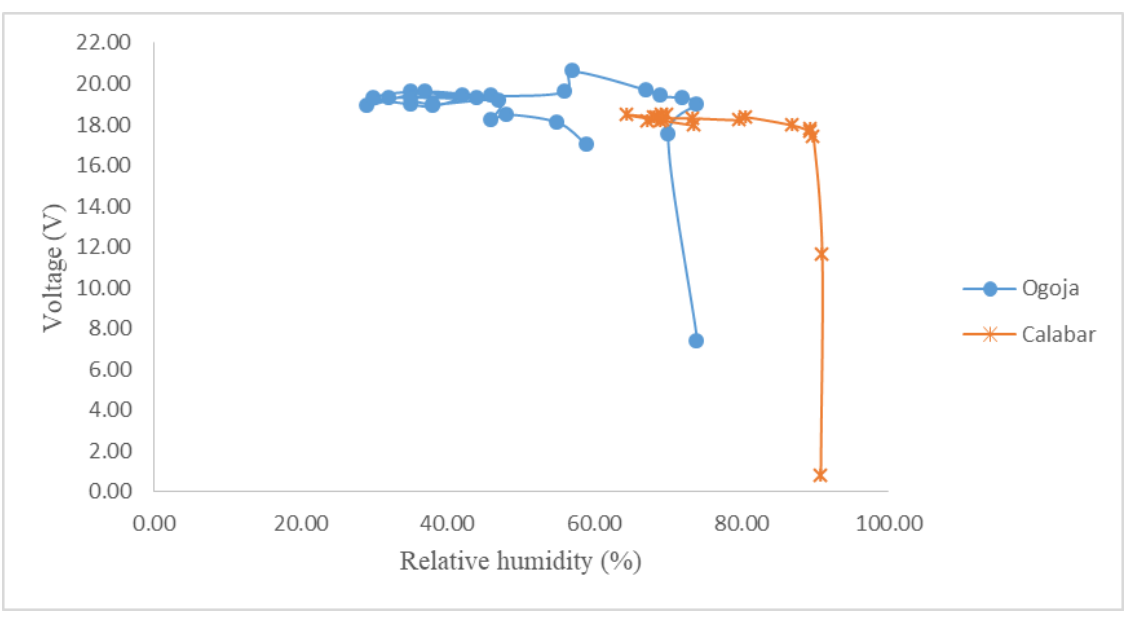

Figure 4 Graph of voltage against relative humidity 
World Journal of Advanced Engineering Technology and Sciences, 2021, 04(01), 011-021

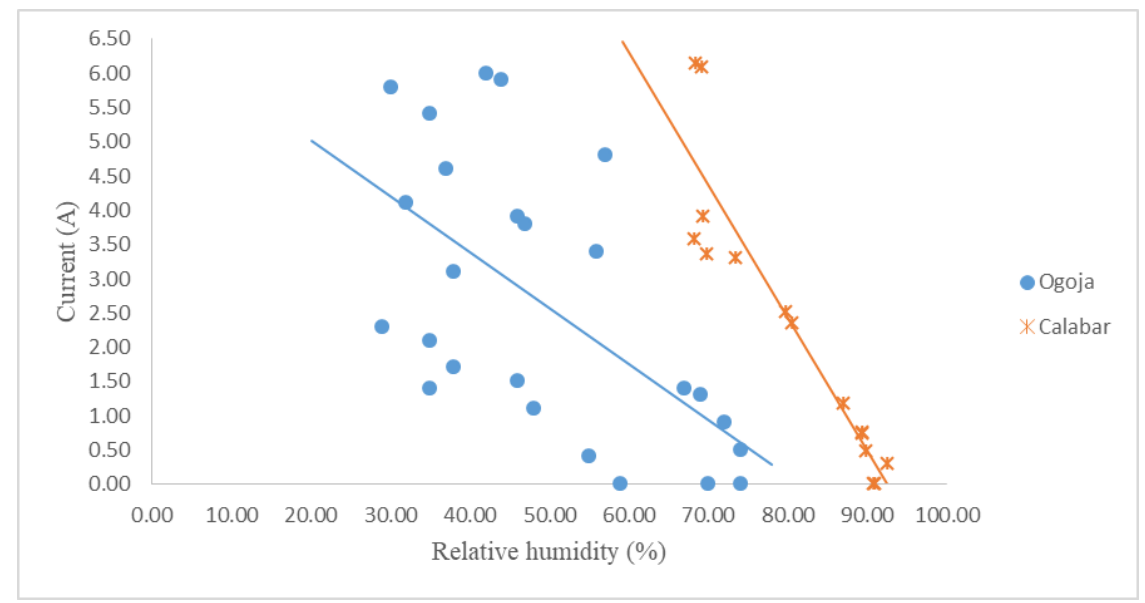

Figure 5 Graph of current against relative humidity

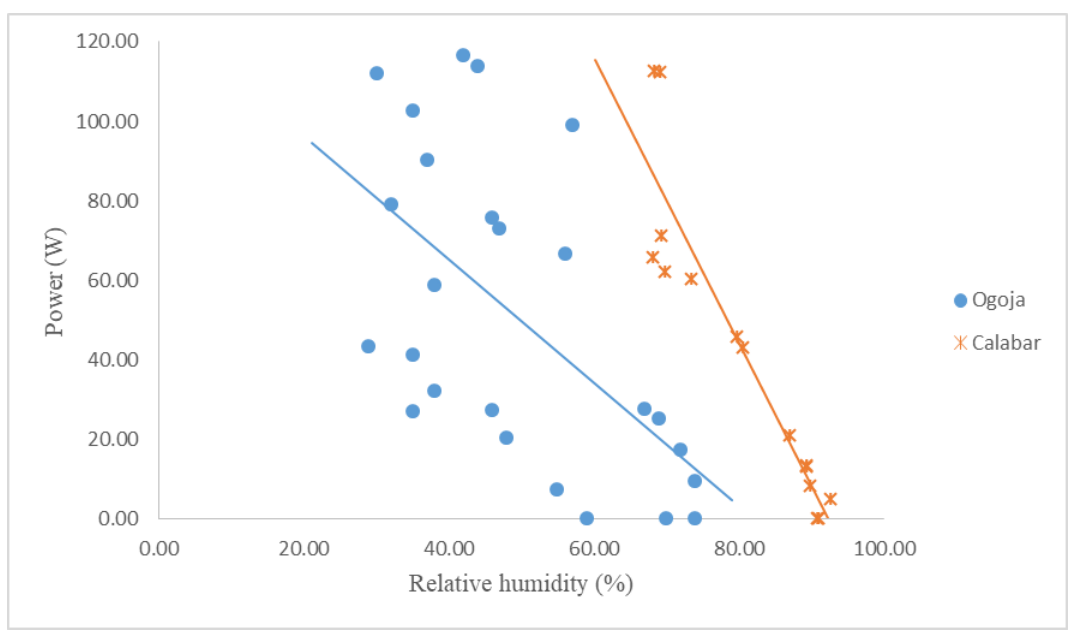

Figure 6 Graph of power against relative humidity

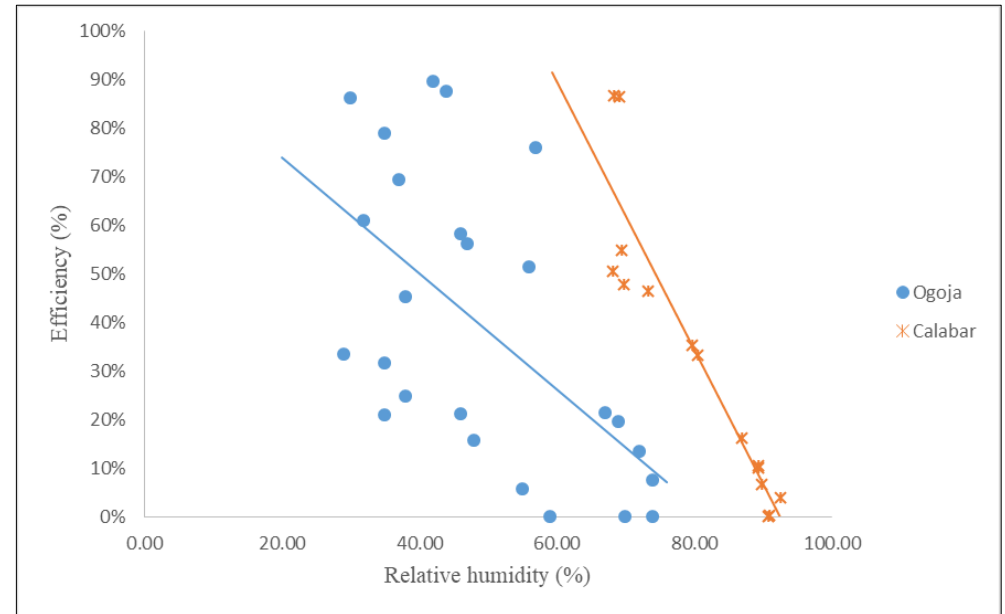

Figure 7 Graph of efficiency against relative humidity 
World Journal of Advanced Engineering Technology and Sciences, 2021, 04(01), 011-021

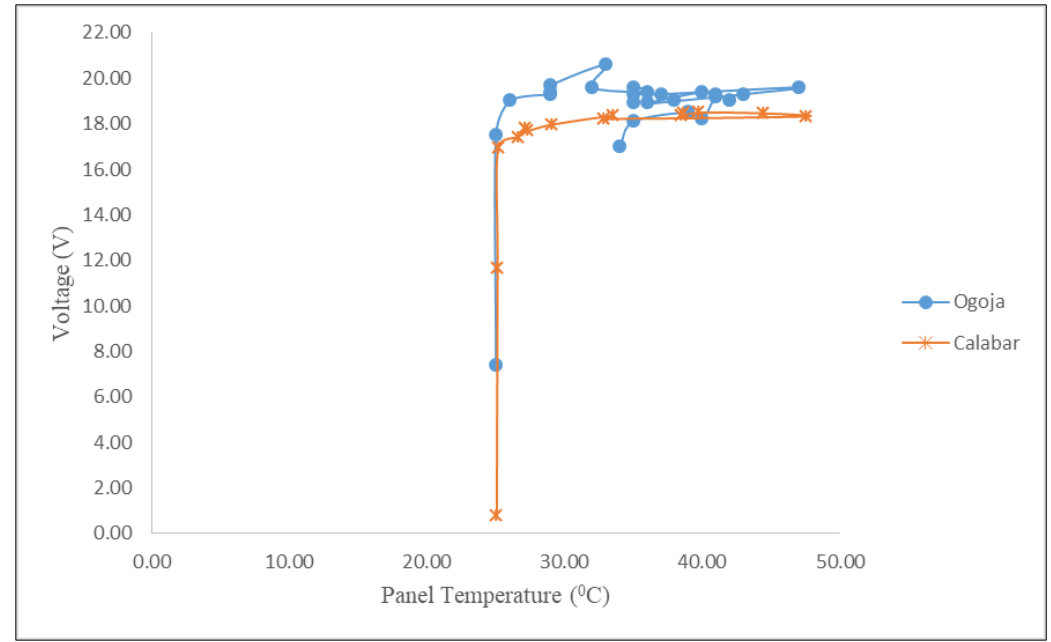

Figure 8 Graph of voltage against panel temperature

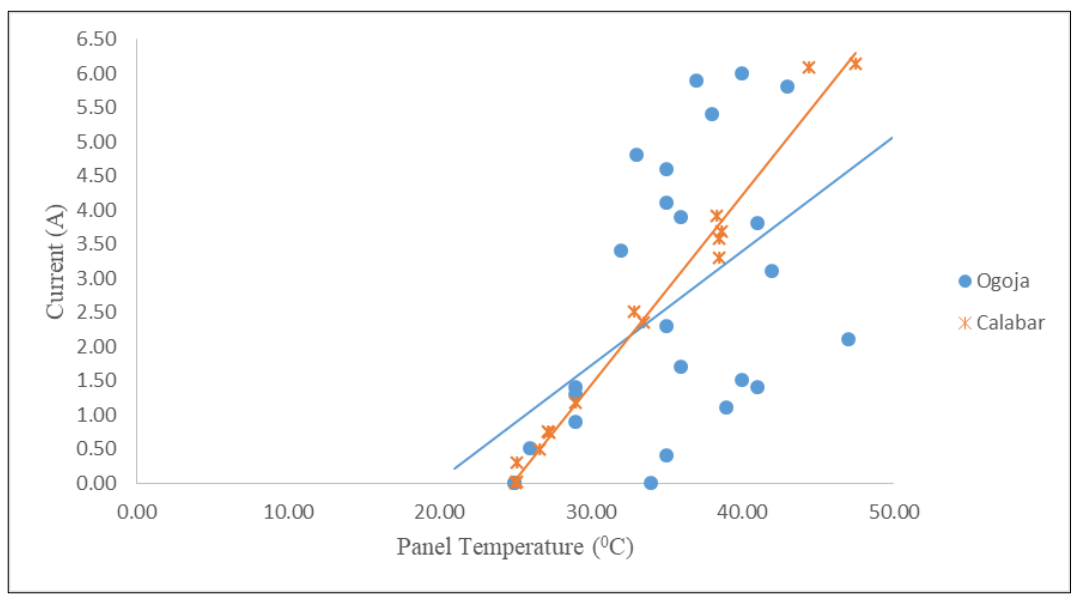

Figure 9 Graph of current against panel temperature

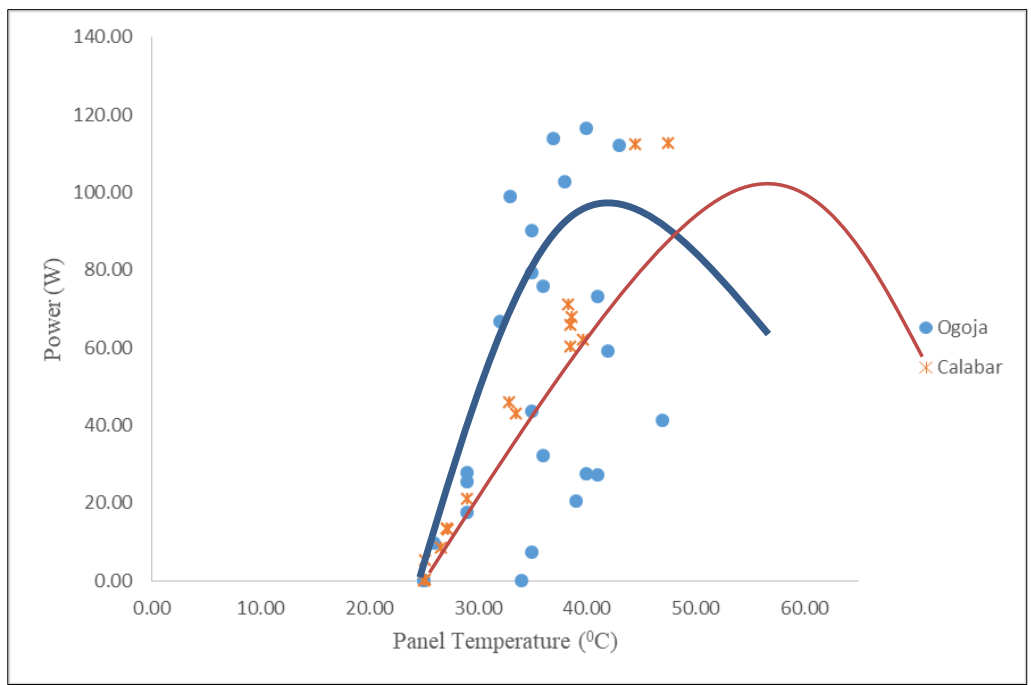

Figure 10 Graph of power against panel temperature 
World Journal of Advanced Engineering Technology and Sciences, 2021, 04(01), 011-021

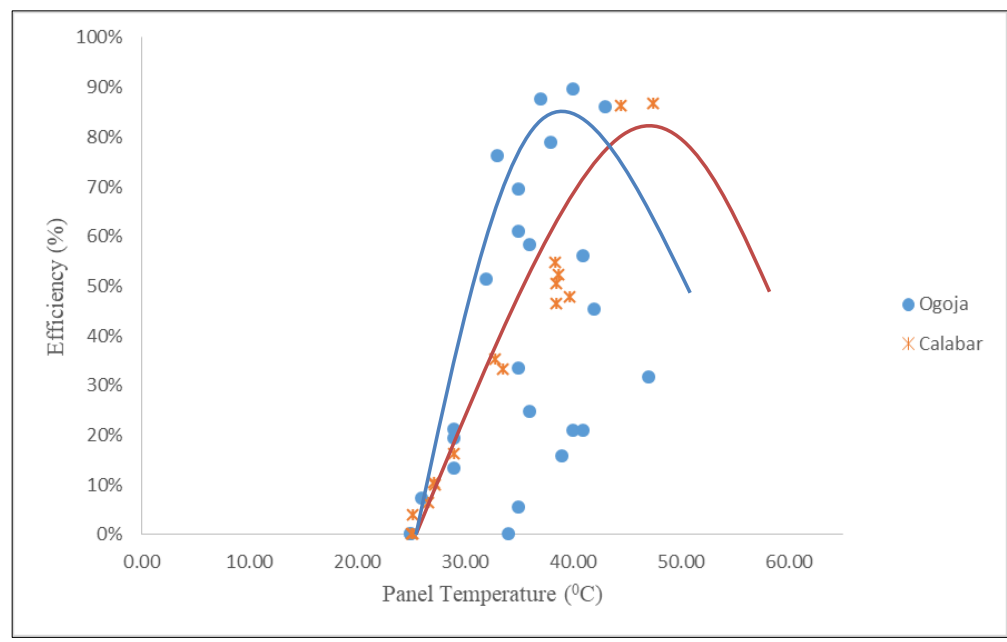

Figure 11 Graph of efficiency against panel temperature

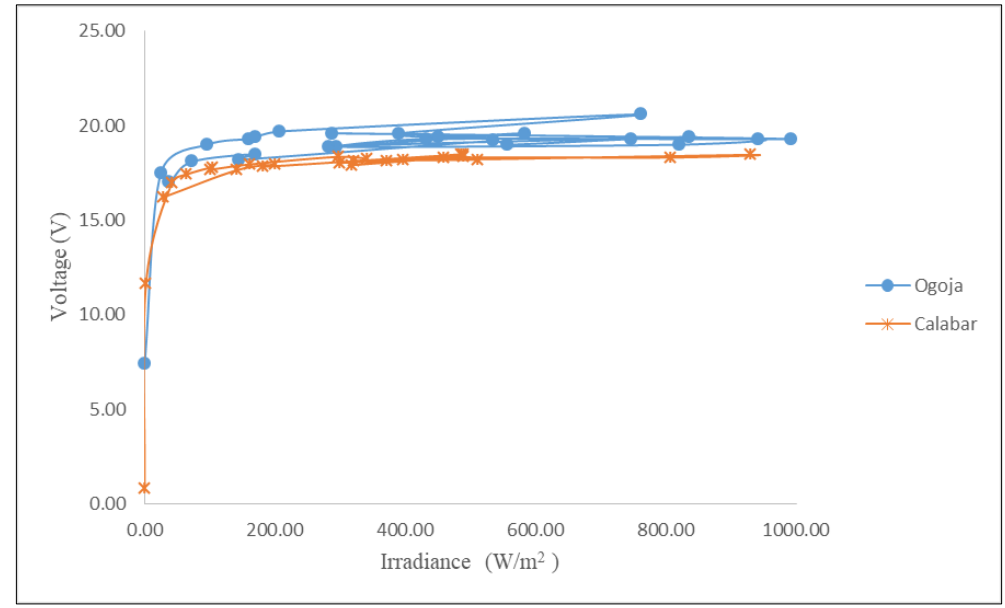

Figure 12 Graph of voltage against irradiance

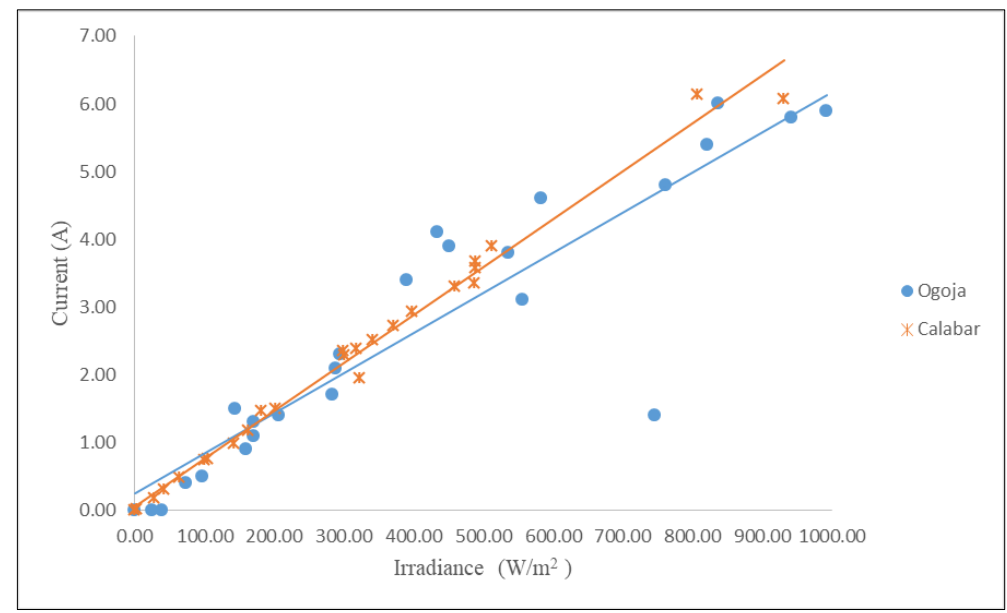

Figure 13 Graph of current against irradiance 
World Journal of Advanced Engineering Technology and Sciences, 2021, 04(01), 011-021

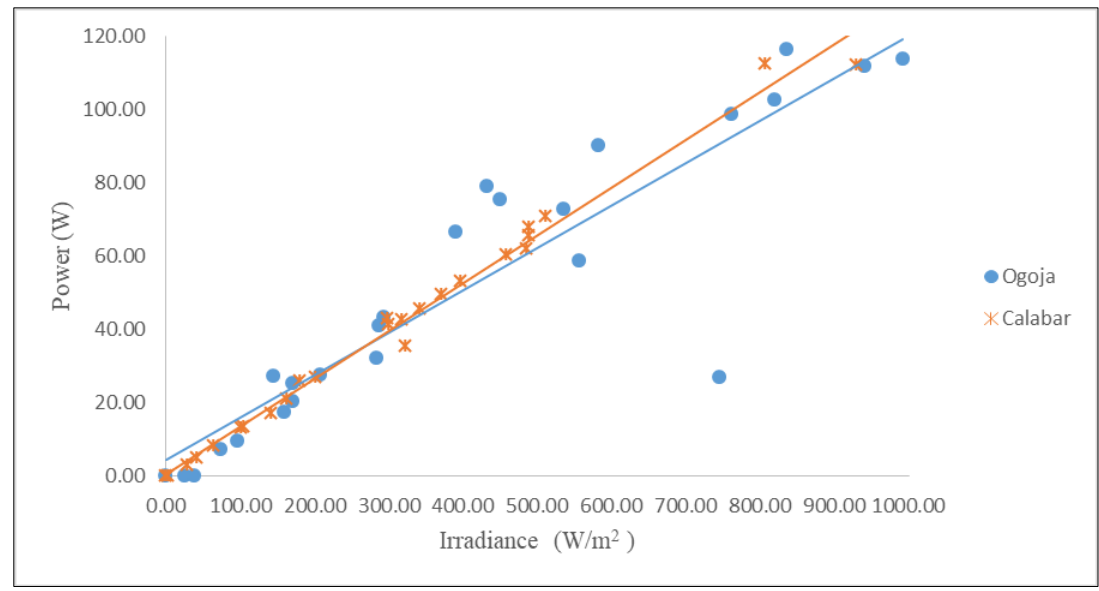

Figure 14 Graph of power against irradiance

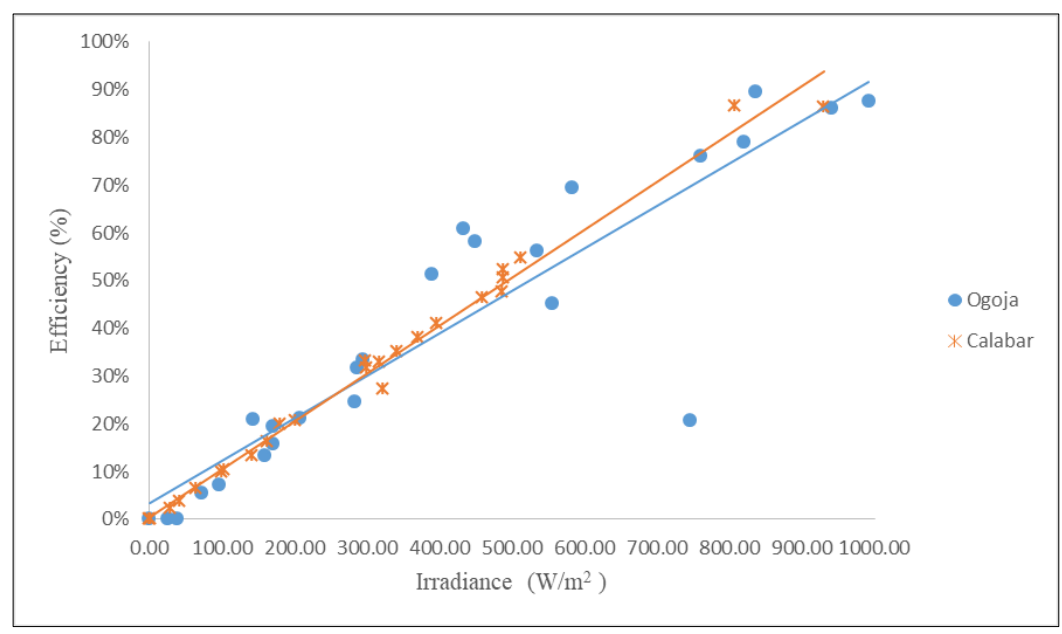

Figure 15 Graph of efficiency against irradiance

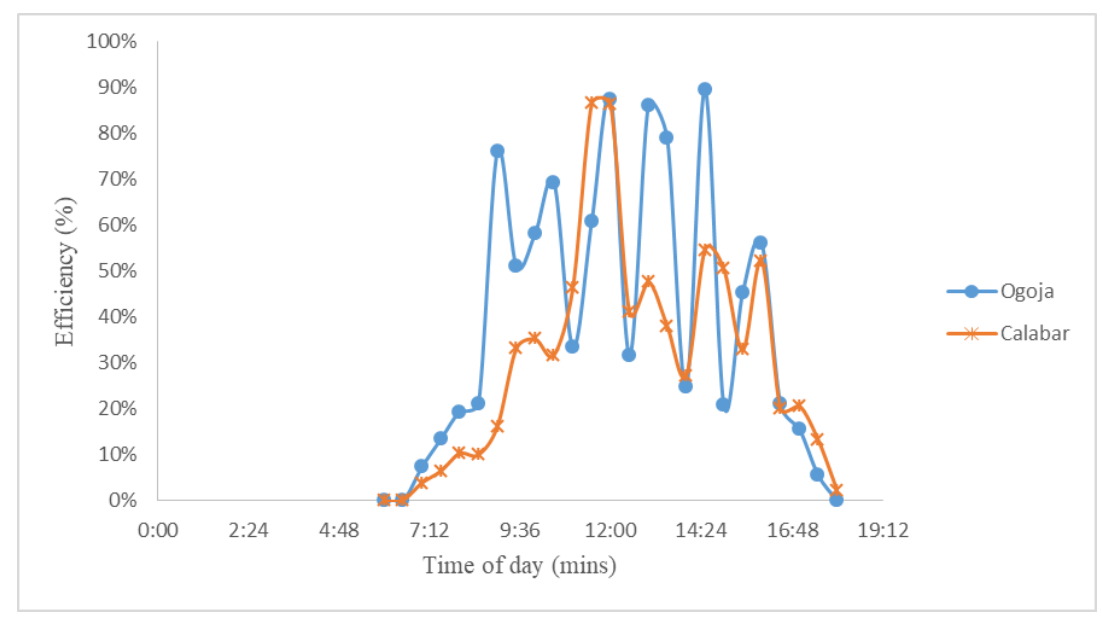

Figure 16 Graph of efficiency against time of day for the photovoltaic modules at both locations 
From the graph it can be seen that for the PV module installed in Calabar, the voltage output remains fairly stable between $64 \%$ to $87 \%$ relative humidity, while above $87 \%$, the voltage begins to drop significantly to zero. For the PV module at Ogoja the voltage output was also fairly stable, but the stability is between $32 \%$ to $56 \%$ relative humidity, while above $57 \%$ the voltage begins to drop to zero which leads to the conclusion that an increase in relative humidity leads to a decrease in voltage. Figure 4 also reveal that the PV module installed at Ogoja performs better than the one in Calabar which gives us an insight that the humidity condition at Ogoja favours the generation of voltage from photovoltaics.

Figure 5 to Figure 7 shows that high relative humidity significantly affects current, power and efficiency of the photovoltaic modules respectively. The graphs reveal that a decrease in relative humidity leads to an increase in the current, power as well as efficiency, which suggest that a linear relationship might exist between relative humidity and current, power and also relative humidity and efficiency produced by photovoltaics. Figure 5 to Figure 7 shows the PV module in Calabar producing higher current which led to higher power as well as efficiency than the other at Ogoja which gives a clue that the relative humidity level in Calabar may be ideal for the generation of electricity via photovoltaics. Results displays by Figure 4 to 7 agrees with work by [12].

Figure 8 which agree with work by [6] shows the modules voltage with temperature. For the PV module installed in Calabar, it can be seen that at temperature between $34{ }^{\circ} \mathrm{C}$ to $40{ }^{\circ} \mathrm{C}$, the module voltage remains fairly constant, while above $40{ }^{\circ} \mathrm{C}$ the voltage begins to drop, giving an insight that high module temperature does not favour voltage performance of photovoltaics. Whereas the voltage performance of the other PV module located at Ogoja displays erratic behaviour which further reveals that high temperature adversely hinders voltage production from photovoltaics.

Figure 9 displays the effect of temperature on the current produced by the photovoltaic modules. The graph shows that current increases linearly as the panel temperature increases.

Figure 10 and Figure 11 depicts the effect of panel temperature on the power and efficiency of the photovoltaic modules respectively. Both figures reveal that the power and efficiency of the PV modules increases as panel temperature increases, but the increase in power and efficiency as panel temperature increases is only up to the maximum operating cell temperature beyond which the power and efficiency begins to drop. Figure 9 and Figure 11 also agree with the work by [6].

Figure 12 shows how the photovoltaic modules installed at the different locations responds to increasing amount of solar power received from the sun. For the module installed in Calabar, it is observed that above an irradiance of $200 \mathrm{~W} / \mathrm{m}^{2}$ the voltage output remains fairly constant irrespective of the amount of solar power received. While for the PV module at Ogoja, poor stability in voltage was observed above an irradiance of $280 \mathrm{~W} / \mathrm{m}^{2}$. Irrespective of the different level of irradiance that revealed their voltage stability, both plots displayed the same shape of graph and the PV module at Ogoja showed better performance in terms of voltage production.

The effects of irradiance on current, power and efficiency of the photovoltaic module can be seen in Figures 13, 14 and 15 respectively. The graphs show that high level of irradiance favours an increase in current, power and efficiency, showing that linear relationships exist between irradiance and current, power and also irradiance and efficiency. Figures 12 to 15 perfectly agrees with studies by [25].

Figure 16 reveals the level of efficiency reached by the photovoltaic module installed at both locations. Form the graph it can be seen that at almost every time of the day, the photovoltaic module installed at Ogoja is at a higher level of efficiency than the one installed in Calabar. The figure further reveal that the efficiencies of the modules are not constant throughout the day as there will be rise and fall in the efficiencies. Furthermore, for photovoltaics installed in Calabar the maximum peak in efficiency should be expected around 12:00pm, while for those at Ogoja triple peaks in efficiencies should be expected between 12:00pm and 2:30pm.

\section{Conclusion}

Performance evaluation of polycrystalline PV modules in a Guinea Savanna and Mangrove Swamp has been investigated and analyzed. Results show that PV modules are most efficient in location with high level of irradiance coupled with low relative humidity and favorable ambient temperature range. Calabar is 32 metres above sea level while Ogoja is 85metres above sea level, and this significant difference in altitude is among the key factors that enabled the photovoltaic module installed at Ogoja to outperform the module installed in Calabar. Due to the triple peaks in efficiency, coupled with the fact that at every time in the day the level of efficiency reached by the PV module at Ogoja 
is higher than that in Calabar, leads to the conclusion that for the month in which study was conducted the weather condition of Ogoja is more favorable for the generation of electricity via photovoltaic technology.

To confirm and ascertain if Ogoja is favorable for the generation of electricity over Calabar by using photovoltaic technology, this research should be carried out for a duration of one year.

\section{Compliance with ethical standards}

\section{Acknowledgments}

We acknowledge all those who assisted us during the data collection and typesetting of this manuscript.

\section{Disclosure of conflict of interest}

The authors declare that there was no conflict of interest.

\section{References}

[1] Ettah EB, Udoimuk AB, Obiefuna JN, Opara FE. The effect of relative humidity on the efficiency of solar panels in Calabar, Nigeria. Universal Journal of Management and Social Sciences. 2012; 2(3): 8-11.

[2] Hussein AK, Miqdam TC. Effect of humidity on photovoltaic performance based on experimental study. International Journal of Applied Engineering Research. 2015; 10(23): 43572-43577.

[3] Panjwani MK, Narejo GB. Effect of altitude on the efficiency of solar panel. International Journal of Engineering Research and General Science. 2014; 2(4): 461-464.

[4] Chegaar M, Hamzaoui A, Namoda A, Petit P, Aillerie M, Herguth A. Effect of illumination intensity on solar cells parameters. Energy Procedia. 2013; 36: 722-729.

[5] Tobnaghi DM, Naderi D. The effect of solar radiation and temperature on solar cells performance. Extensive journal of applied sciences. 2015; 3(2): 39-43.

[6] Omubo-Pepple VB, Isreal-cookey C, Alaminokuma GI. Effects of Temperature, Solar Flux and Relative Humidity on the Efficient Conversion of Solar Energy to Electricity. European Journal of Scientific Research. 2009; 35(2): 173-180.

[7] Touati F, Massoud A, Hamad A, Saeed SA. Effects of environmental and climatic conditions on PV efficiency in Qatar. Renewable Energy and Power Quality Journal. 2013; 1(11): 262-267.

[8] Rani SP, Giridhar SM, Prasad SR. Effect of temperature and irradiance on solar module performance. IOSR Journal of Electrical and Electronics Engineering. 2018; 13(2): 36-40.

[9] Syafiqah Z, Irwan YM, Amin NAM, Irwanto M, mil WZ, Amelia AR. Thermal and Electrical Study for PV Panel with Cooling System. Indonesian Journal of Electrical Engineering and Computer Science. 2017; 7(2): 492-499.

[10] Dietz AG. Diathermanous materials and properties of surface, in zaren: Introduction to the utilization of solar energy. New York: McGraw Hill. 2002; 359.

[11] El-Shaer A, Tadros MT, Khalifa MA. Effect of light intensity and temperature on crystalline silicon solar modules parameters. International Journal of Emerging Technology and Advanced Engineering. 2014; 4(8): 311-318.

[12] Ettah E, Ekah U, Oyom E, Akonjom N. Performance Analysis of Monocrystalline and Polycrystalline Solar Panels in a Semi-Arid Region. International Journal of Engineering Science Invention. 2021; 10(7): 10-14.

[13] Ettah EB, Eno EE, Udoimuk AB. The Effects of Solar Panel Temperature on the Power Output Efficiency in Calabar, Nigeria. Journal of Association of Radiographers of Nigeria. 2009; 23: 16-22.

[14] Siddiqui R, Bajpai U. Deviation in the performance of Solar Module under climatic parameter as Ambient Temperature and Wind Velocity in Composite Climate. International Journal of Renewable Energy Research. 2012; 2(3): 486-490.

[15] Bhattacharya T, Chakraborty AK, Pal K. Effects of Ambient Temperature and Wind Speed on Performance of Monocrystalline Solar Photovoltaic Module in Tripura, India. Journal of Solar Energy. 2014;1- 5. 
[16] Berthod C, Strandberg R, Yordanov GH, Beyer HG, Odden JO. On the variability of the temperature coefficients of mc-Si solar cells with irradiance. Energy Procedia. 2016; 92: 2-9.

[17] Hamrouni N, Jraidi M, Cherif A. Solar radiation and ambient temperature effects on the performances of a PV pumping system. Revue des Energies Renouvelables. 2008; 11(1): 95-106.

[18] Omubo-Pepple VB, Tamunobereton-ari I, Briggs-Kamara MA. Influence of meteorological parameters on the efficiency of photovoltaic module in cities in the Niger Delta of Nigeria. Journal of Asian scientific research. 2013; 3(1): 107-113.

[19] Ettah EB, Obiefuna JN, Njar GN. The relationship between solar radiation and the efficiency of solar panels in Port Harcourt, Nigeria. International Journal of Applied Science and Technology. 2011; 1(4): 124-126.

[20] Panjwani MK, Narejo GB. Effect of humidity on the efficiency of solar cell (photovoltaic). International Journal of Engineering Research and General Science. 2014; 2(4): 499-503.

[21] Hussein AK, Miqdam TC, Iman MA, Hanan Saif A, Hanan Sulaiman A, Jamila KA, Ali HA. Effect of humidity on the PV performance in Oman. Asian Transaction on Engineering. 2012; 2(4): 29-32.

[22] Kamgba FA, Edet CO, Njok AO. Effects of some Meteorological Parameters on Wind Energy Potential in Calabar, Nigeria. Asian Journal of Physical and Chemical Sciences. 2017; 4(1): 1-7.

[23] Weatherbase. "Ogoja, Nigeria”. 2021.

[24] Njok AO, Ogbulezie JC. The effects of relative humidity and temperature on polycrystalline solar panels installed closed to a river. Physical Science International journal. 2018; 20(4): 1-11.

[25] Njok AO, Kamgba FA, Panjwani MK, Mangi FH. The influence of solar power and solar flux on the efficiency of polycrystalline photovoltaics installed close to a river. Indonesian Journal of Electrical Engineering and Computer Science. 2020; 17(2): 988-996. 